\title{
The gearing adjustment of AC 201: Comparison with SSAP 16 and Philips 1981
}

\author{
M.A. van Hoepen \\ Touche Ross Netherlands/Touche Ross International, 700 van Alkemade Avenue, 2597 AW The Hague, The Netherlands \\ I.J. Lambrechts* and F.J. Mostert \\ Department of Business Economics, University of Stellenbosch, Stellenbosch 7600, Republic of South Africa
}

\begin{abstract}
The objective with this article is to analyse and compare the method of calculating the gearing adjustment as applied in the United Kingdom (SSAP 16), the Netherlands (Philips 1981 version) and South Africa (Guideline AC 201). It could be read together with Van Hoepen, Lambrechts and Mostert (1989). The gearing adjustment is an important step in inflation accounting because it recognizes the fact that a certain portion of assets could be financed in such a way that the detrimental effect of inflation is decreased. Important differences in gearing adjustment methods could result in different conclusions drawn from the analysis of financial statements and could consequently influence the financial investment decision, especially in a period of galloping inflation. The main conclusion from the comparison of the three systems is that they result in the same total adjustments over a period of time but that there are important differences over the medium and short term as well as in the present values of these adjustments. The three systems result in full capital maintenance of equity capital over time, in the case of both net monetary liabilities and assets.
\end{abstract}

\begin{abstract}
Die doelwit van hierdie artikel is om die berekeningsmetode van die hefboomaansuiwering soos toegepas in Brittanje (SSAP 16). Nederland (Philips 1981) en Suid-Afrika (Riglyn RE 201) te ontleed en vergelyk. Die artikel kan saam met Van Hoepen, Lambrechts en Mostert (1989) gelees word. Die hefboomaansuiwering is 'n belangrike stap by inflasie-rekeningkunde omdat dit erkenning gee aan die feit dat 'n sekere gedeelte van bates so gefinansier kan wees dat die nadelige gevolg van inflasie verminder. Belangrike verskille in metodes om hefboomaansuiwerings te bereken, kan tot verskillende afleidings by die ontleding van finansiële state lei en dit kan ook die investeringsbesluit beïnvloed, veral in 'n periode van hö inflasiekoerse. Die belangrikste afleiding uit die vergelyking van die drie metodes is dat hulle tot dieselfde aansuiwerings oor die lang termyn lei, maar dat dasr belangrike verskille oor die medium sowel as kort termyn is, sowel as in die teenswoordige waardes van die ansuiwerings. Die drie metodes lei tot volle kapitaalhandhawing van die kapitaal oor tyd by 'n situasie van beide netto monetêre laste en bates.
\end{abstract}

*To whom correspondence should be addressed.

\section{Introduction}

The application of a gearing adjustment in current cost and inflation accounting systems has always brought about the problem of stating a financing sequence. An explicit decision must be taken of how certain categories of assets are financed with equity and/or loan capital. The assumption on the financing sequence cannot be made on a logical or theoretical basis. Therefore the choice must be made on the basis of the economic consequences. The economic consequences of this choice have never been paid much attention to, neither in theory nor in practice.

The objective of this article is to analyse and compare the method of the gearing adjustment as applied in the United Kingdom (SSAP 16), the Netherlands (Philips 1981-version) and South Africa (Guideline AC201). This analysis and comparison will point out the differences between the gearing adjustments and the effect on the financial statements. Important differences could result in different conclusions based on an analysis of financial statements and could consequently influence the financial investment decision, especially in a period of galloping inflation.

The outline adopted in this article is first to describe and illustrate the method of gearing adjustments in the different countries, secondly to investigate the position in a situation of net monetary liabilities, and lastly to investigate the position in a situation of net monetary assets.
The same example is used throughout the article and comparisons are made in the first year, from the second year until the end of the lifetime of the asset, as well as for the total lifetime of an asset.

\section{Netherlands (Phillps 1981-system)}

Since the 1981 financial year Philips adopted a two-step approach in its income statement. In 1983 this approach was abandoned. Philips has since compiled its 'primary' financial statements on a current cost basis and supplemented these with ('secondary') statements of valuation and income determination on a historical cost basis. The reason for using the 1981 system, instead of the present application of current cost accounting, is that the 1981 system can be excellently compared with SSAP 16 and RE 201; much better than the present system. Moreover, the present financing assumption by Philips does not differ materially from that in the 1981 system.

In the 1981 system the gearing adjustment (addition to realised revaluation owing to financing with equity capital) is subtracted from trading income on a historical cost basis. The reason is that part of the revaluation is financed with equity capital with the result that the original addition to realised revaluation is too high. Equity capital therefore serves primarily to finance nonmonetary assets (tangible assets, or as Philips called it, 'assets liable to revaluation'), for example fixed assets and stocks.

The system can be illustrated with a simple example, 
which will also be used to illustrate the adjustments of the other systems. On 1 January 1978 a company acquires a fixed asset (A) for RI 000 ; its residual value is nil and its useful life is 10 years. Depreciation is according to the straight-line method. On 2 January 1978 the price of the asset shows an increase of $20 \%$. In the years 1978 to 1988 the annual income before depreciation (and the net cash flow) is $R 300$.

The opening balance sheet is as follows:

Balance sheet (1 January 1978)

\begin{tabular}{|c|c|c|c|}
\hline \multirow[t]{2}{*}{$\begin{array}{l}\text { Equity capital (SC) } \\
\text { Loan capital (EC) }\end{array}$} & $\begin{array}{r}800 \\
1200\end{array}$ & $\begin{array}{l}\text { Asset (A) } \\
\text { Cash (C) }\end{array}$ & $\begin{array}{l}1000 \\
1000\end{array}$ \\
\hline & 2000 & & 2000 \\
\hline
\end{tabular}

Depreciation on a historical cost basis amounts to 100 per annum and on a current cost basis to R120. All irrelevant details are ignored in the analysis of the financing assumption (also in the analysis of the other two gearing adjustments), such as:

- the treatment of deferred tax (a non-tax situation is assumed);

- recurring price increases (there is only one nonrecurring price increase); and

- the question whether the gearing adjustment should be based on the balance sheet at the beginning of the year, at the end of the year or on an 'average' balance sheet. The gearing adjustment is based on the balance sheet of 1 January 1978 (and for SSAP 16 and RE 201 as well).

The gearing adjustment in the 1981 system is on the basis of the relationship between equity capital and nonmonetary assets. Therefore the machine is supposed to have been financed for $800 / 1000=80 \%$ with equity capital. The revaluation of the machine on 2 January can be analysed as follows:

\begin{tabular}{ll}
\hline Total revaluation: & Financed with equity capital $(80 \%)=R 160 ;$ \\
R200 on 2 January & realised R16 per year \\
1978; realised & Financed with loan capital $(20 \%)=R 40 ;$ \\
revaluation & realised $R 4$ per year. \\
R20 per year & \\
\hline
\end{tabular}

The income statement for 1978 is as follows:

Income statement 1978 (Philips 1981-system)

Sales

R300

Less: Cost of sales (say only deprecistion)

on a current cost besis

Trading income on a current cost basis

Plus: Revaluation included in cost (200/10)

Trading income on a historical cost besis

Less: Addition to reslised revaluation owing to

financing with equity cepital $(800 / 1000 \times 20)$

Net income (distributable income)

120

\section{United KIngdom (SSAP 16)}

The SSAP 16 income statement starts with historical cost income. Current cost operating income is derived after making three adjustments:

- the cost-of-sales adjustment (COSA);

- the depreciation adjustment (DA); and

- the monetary-working-capital adjustment (MWCA).

The SSAP 16 gearing adjustment is based on the relationship between loan and total capital. After the deduction of the 'realised revaluations' (COSA and DA) and after the deduction of the MWCA, too much is deducted from historical cost income. So the gearing adjustment added to current cost income is essentially:

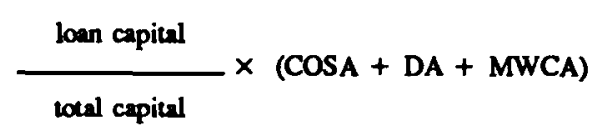

In order to make the system comparable to the Philips system in the area of the financing assumption, the assumption is made that the MWCA will be calculated on the basis of the specific price increase of the machine and that the only monetary working capital is the amount of cash available on 1 January 1978.

It is difficult to say what the exact financing assumption of SSAP 16 really is. At first glance it appears to be a proportional financing assumption, because the gearing adjustment is calculated on the basis of the relationship of loan capital to total capital. It should be taken into account that the proportion of loan capital to total capital is multiplied not only by the COSA and DA (realised value increases) but also by the MWCA. By doing so the basic financing assumption of SSAP 16 is essentially that loan capital serves primarily to finance monetary assets.

The 1978 income statement in the example is as follows:

\section{Income statement 1978 (SSAP 16 system)}

Sales

Less: Cost of sales (say only depreciation)

on a historical cost basis

Operating income on a historical cost basis

Less: COSA+DA (200/10)

MWCA $(1000 \times 20 \%)$

R300

Operating income on a current cost besis

Plus: Gearing adjustment 1200/2000 $\times 220$

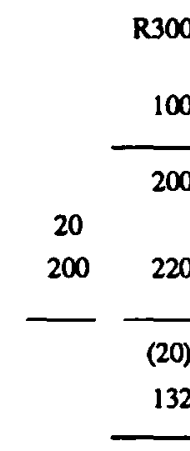

Current cost income attributable to shareholders

112

\section{South Africa (Guldeline AC201)}

As SSAP 16, the AC 201 current cost income statement starts from the opposite direction than the Philips income statement. The current cost adjustments are being deducted from operating income per historical financial statements, resulting in entity operating income, which represents current cost operating income. The gearing adjustment is added to this figure to get the 
owners' income. The gearing adjustment in the case of net monetary liabilities (NML) is calculated according to the ratio NML to (NML + equity capital). In the case of net monetary liabilities the financing assumption of $\mathrm{AC}$ 201 is that monetary liabilities serve primarily to finance monetary assets.

The income statement starts from a different angle than that of Philips (from historical cost income and not from current cost income), so does the financing assumption (monetary liabilities serve primarily to finance monetary assets), compared to Philips' assumption where equity capital serves primarily to finance non-monetary assets. It is clear that in the case of net monetary liabilities the owners' income of AC 201 must be equal to the net income (distributable income) of Philips.

The income statement in our example for the Guideline AC 201 system is as follows:

\section{Income statement 1978 (AC 201 system)}

Sales

Less: Cost of sales on a historical cont basis

(ay only depreciation)

Operating income per historical cost stetements

Less: Current cost adjustment

Entity income

Plus: Gearing adjustmen $20 \times(1200-1000) /(1200-1000+800)$

Owners" income

$\mathbf{R} 300$

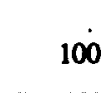

200

20

180

4

184

The financing assumption in the case of net monetary liabilities

The 1978 income statements, in more or less equivalent terminology, are given in Table 1.

The lower SSAP 16 distributable income for 1978 is caused by the fact that the total MWCA is charged immediately and in total to the (1978) income statement of the year in which the (specific) price increases erode monetary working capital. The specific price increases on non-monetary assets have their effect on the income statement only in the year that these price increases are realised. The MWCA is charged immediately to the income statement and COSA/DA only upon realisation (according to the depreciation in the example).

The distributable income per annum according to SSAP 16 from 1979 onwards, will amount to R192, that

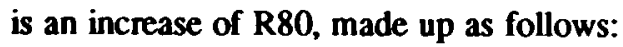

No MWCA

R200

Docrease in gearing adjustment $(1200 / 2000 \times 200)$

R120

80

Because there is no further price increase the difference between Philips and AC 201 on the one hand and SSAP 16 on the other hand continues until the end of the lifetime of the machine. The initial positive surplus of R72 (184-112) is completely eliminated by
Table 1 Comparative 1978 income statements in the case of net monetary liabilities

\begin{tabular}{|c|c|c|c|}
\hline & Philips & SSAP 16 & AC201 \\
\hline Sales & 300 & 300 & 300 \\
\hline \multicolumn{4}{|l|}{ Less: Depreciation: } \\
\hline Current cost & 120 & & \\
\hline Historical cost & & 100 & 100 \\
\hline \multicolumn{4}{|l|}{ Operating income: } \\
\hline Current cost & 180 & & \\
\hline Historical cost & & 200 & 200 \\
\hline Plus: Historical cost adjustment & 20 & & \\
\hline \multicolumn{4}{|l|}{ Less: Current cost adjustments } \\
\hline $\operatorname{COSA}+\mathrm{DA}$ & & 20 & 20 \\
\hline MWCA & & 200 & \\
\hline \multicolumn{4}{|l|}{ Operating income/entity income } \\
\hline Historical cost & 200 & & \\
\hline Current $\cos t$ & & (20) & 180 \\
\hline \multicolumn{4}{|l|}{ Gearing adjustment } \\
\hline $800 \times 20$ & (16) & & \\
\hline \multicolumn{4}{|l|}{1000} \\
\hline \multicolumn{4}{|l|}{1200} \\
\hline \multicolumn{4}{|l|}{2000} \\
\hline \multicolumn{4}{|l|}{200} \\
\hline$\frac{1000}{100} \times 20$ & & & 4 \\
\hline \multicolumn{4}{|l|}{ Distributable income/current cost } \\
\hline income/owners' income & 184 & 112 & 184 \\
\hline
\end{tabular}

the negative difference of [R72 (192-184)9] at the end of the 10-year period. The accumulated distributable income is therefore the same for all three methods, that is $\mathrm{Rl} 840$.

\section{Comments on the financing assumptions in the case of net monetary liabilities}

The similarity between the financing assumptions in the case of net monetary liabilities is clear from the above figures. The difference between Philips 1981 and AC 201 is more or less a matter of semantics. To assume that equity capital serves primarily to finance non-monetary assets is basically the same as saying that monetary liabilities serve primarily to finance monetary assets. The explanation for the similarity between Philips and AC 201 on the one hand and SAPP 16 on the other, lies in the fact that the ratio loan to total capital is not only multiplied with realised value increases (COSA and DA) but also with the MWCA, thus resulting in the same financing assumption as Philips and AC 201. In SSAP 16 there is an inconsistency because the MWCA influences income in full in the year of a price increase (1978 in the example) whereas the effect of price increases on nonmonetary assets is deferred until realisation in the other systems. The financing assumptions of AC 201, SSAP 16, and Philips lead to full maintenance of the specific purchasing power of equity capital (or substantialistic 
capital maintenance of equity capital). After distribution of all income that is regarded as distributable income, the ending balance sheet under all three systems will be:

Ending balance sheet after income distribution on 31 December 1987

\begin{tabular}{|c|c|c|c|c|}
\hline Equity capital & & & Fixed asset & 0 \\
\hline Opening balance & 800 & & Cash: Opening balance & 1000 \\
\hline Reserves") & 160 & 960 & Net cash flow $(300 \times 10)$ & 3000 \\
\hline Loen capital & & 1200 & Income distributed & (1840) \\
\hline & & 2160 & & 2160 \\
\hline
\end{tabular}

The degree of capital maintenance of equity capital must be analysed assuming that the amount of income that is regarded to be distributable is in fact distributed. This does not mean that a company should distribute total distributable income. Substantialistic capital maintenance, or the maintenance of the specific purchasing power of capital, is an attempt to analyse the consequences of an income determination in terms of assets instead of in terms of money. Therefore, it can be said that on 1 January 1978 equity capital represented 0,8 machine, the equity capital in terms of money amounted to $R 800$, whereas the current cost of the machine was $R 1000$ at that time. After income distribution equity capital amounted to R960 on 31 December 1987.

At that time, however, the price of a new machine was R1200. The equity capital on that date therefore represented $(960 / 1200)=0,8$ machine. In other words, the degree of substantialistic capital maintenance of equity capital was

$\frac{960 / 1200}{800 / 1000} \times \frac{100}{1}=100 \%$

The gearing ratio changes to the same degree as the specific price increase. In other words, if a company wants to maintain the same degree of relative exposure with regard to its investments in assets, it has to increase cash with an amount of R240. Cash after income distribution being $R 2160$, an amount of $R 960$ remains after the purchase of a new machine. In order to increase cash to $50 \%$ of the balance sheet total (the original exposure) an increase of R240 in cash is necessary. This R240 can be acquired in the form of loan capital and will thereby increase the loan capital ratio to $60 \%$ which equals the original ratio.

\section{The financing assumption in the case of net monetary assets}

For the Philips system it is not quite clear from its annual accounts what will happen in the case of net monetary assets because this situation has never occurred for the company as a whole. Their manual prescribes an additional charge to the income statement equal to the effect of the specific price increase on net monetary
Table 2 Comparative 1978 income statements in the case of net monetary assets

\begin{tabular}{|c|c|c|c|}
\hline & Philipe & SSAP 16 & AC201 \\
\hline Sales & 300 & 300 & 300 \\
\hline \multicolumn{4}{|l|}{ Less: Depreciation: } \\
\hline Current cost & 120 & & \\
\hline Historical cost & & 100 & 100 \\
\hline \multicolumn{4}{|l|}{ Operating income: } \\
\hline Current cost & 180 & & \\
\hline Historical cost & & 200 & 200 \\
\hline Plus: Historical cost adjustment & 20 & & \\
\hline \multicolumn{4}{|l|}{ Less: Current cost adjustments } \\
\hline $\cos A+D A$ & & 20 & 20 \\
\hline MWCA & & 200 & \\
\hline \multicolumn{4}{|l|}{ Operating income/entity income } \\
\hline Historical cost & 200 & & \\
\hline Current cost & & (20) & 180 \\
\hline \multicolumn{4}{|l|}{ Gearing adjustment } \\
\hline$\stackrel{1200}{1} \times 20$ & (24) & & \\
\hline \multicolumn{4}{|l|}{1000} \\
\hline \multicolumn{4}{|l|}{800} \\
\hline \multicolumn{4}{|l|}{2000} \\
\hline $20 \% \times 200$ & & & (40) \\
\hline Distributable income & 176 & 68 & 140 \\
\hline
\end{tabular}

assets. In other words the ratio equity capital/net monetary assets is also fully applied to calculate the gearing adjustment in the case of net monetary assets. AC 201 introduces an explicit (specific) purchasing power loss in the case of net monetary assets. The 1978 income statements in more or less equivalent terminology are as follows for the different systems. The case of net monetary assets is illustrated with the same example but at different opening balance sheet, which is as follows:

Balance sheet on 1 January 1978

Equity capital 1200 Asset 1000

Loan capital 800 Cash 1000

$2000 \quad 2000$

Comparative 1978 income statements are given in Table 2.

The distributable income in the case of the Philips system remains unchanged until the end of the lifetime of the asset, that is a total of R1760 for the 10-year period. For the SSAP 16 system this figure changes to R188 $(68+200-(800 / 2000 \times 200))$, that is a total of R1760 over the lifetime of the asset. The AC201 figure increases to R180 $(140+40)$; resulting also in a total figure of R1760. 


\section{Comments on the financing assumptions in case of net monetary assets}

The similarity between the financing assumptions in the case of net monetary assets is again clear from the above cumulative income statements. The assumption that equity capital serves primarily to finance non-monetary assets is basically the same as saying that monetary liabilities serve primarily to finance monetary assets. The explanation for the similarity between Philips and AC201 on the one hand and SSAP 16 on the other hand is the same as in the case of net monetary liabilities.

The inconsistency of SSAP 16, namely that the MWCA adjustment influences income in full in the year of a price increase, whereas the influence of the same price increase on non-monetary assets (that is COSA and DA) is deferred until realisation takes place, applies also in the case of net monetary assets. The same inconsistency now applies to $\mathrm{AC} 201$, because in the case of net monetary assets, AC201 can be said to apply a monetary (working) capital adjustment (although 'disguised' as a negative gearing adjustment) to the net monetary assets. In AC201 this effect is mitigated by the fact that the adjustment applies only to net monetary assets, whereas the adjustment in SSAP 16 applies to total monetary working capital (all monetary assets in the example).

One could argue that as the price increase occurred in 1978 the effect on monetary working capital (SSAP 16) or the effect on net monetary assets (AC201) had a causal relationship with 1978 and therefore it should be charged to the 1978 income statement; thus, implying that the Philips system gives rise to (intolerable?) income smoothing. On the other hand one could argue that there is some inconsistency in deferring the effect of price increases on non-monetary assets whilst not doing so for monetary assets. In this respect SSAP 16 is consistent in its inconsistency. AC201 shows this inconsistency only in the case of net monetary assets. However, who could argue that the income smoothing effect of Philips (and AC201 in the case of net monetary liabilities) is not true and fair? Or who could argue that the consistent inconsistency of SSAP 16 is better than the inconsistency of $\mathrm{AC201}$ ?

In the case of net monetary assets there is full physical capital maintenance of equity capital. After distribution of income that is said to be distributable the ending balance sheet under all three systems would be:

\section{Ending balance sheet after income distribution 31 December 1978}

\begin{tabular}{|c|c|c|c|c|c|}
\hline Equity copital & & & Fixed asset & & $\mathbf{0}$ \\
\hline (opening belence) & 1200 & & & & \\
\hline Reserves $x$ & 240 & & & & \\
\hline & & 1440 & Cash: Opening balance & 1000 & \\
\hline & & & Net cash flow & 3000 & \\
\hline Loan capital & & 800 & Income distribution & $(1760)$ & 2240 \\
\hline & & 2240 & & & 2240 \\
\hline
\end{tabular}

The equity capital on $31 / 12 / 1987$ represents $1440 / 1200$ $=1,2$ machine compared to $1200 / 1000=1,2$ on $1 / 1 / 1978$ resulting in a $100 \%$ substantialistic maintenance of equity capital. Also in case of net monetary assets the gearing ratio (1200/800 on 1 January 1978) changes to exactly the same degree as the specific price increase, becoming 1440/800 on 31 December 1987.

After repurchasing a new machine at a cost of R1200 the remaining cash amounts to R1040 (2240-1200). In order to make cash again $50 \%$ of the balance sheet total (thus restoring the initial exposure) R160 can be attracted as loan capital without a deterioration of the initial gearing ratio. The exposure and gearing on the closing balance sheet is therefore the same as the initial situation, as is evident from the following figures:

\begin{tabular}{lcllll} 
& $R \quad \%$ & $R$ & $\%$ \\
\hline SC & 1440 & 60 Fixed asset & 1200 & 50 \\
LC 800+160) & 960 & 40 Cash $(2240-1200+160)$ & 1200 & 50 \\
\cline { 2 - 3 } & 2400 & 100 & $\frac{2400}{100}$ &
\end{tabular}

\section{Conclusion}

Although the three systems result in the same figures over a period of time, important differences and consequently differences in conclusions could result over the medium and short term. Philips 1981 and AC201 result in the same figures per annum in the case of net monetary liabilities. These two differ from SSAP 16 per annum because of its monetary-working-capital adjustment (MWCA) but give the same results over a period of time in the case of the single asset. In the case of diversity of the assets there will also be differences over a longer period of time.

In the case of net monetary assets, all three methods give different results per annum but the same results over a longer period of time in the case of a single asset. AC201 calculates a working capital adjustment based on net monetary assets in the form of a gearing adjustment.

The three systems result in full capital maintenance of equity capital over time, in the case of both net monetary liabilities and assets.

A financial analyst should be careful in analysing financial statements based on inflation adjustments. Ample provision should be made for differences in systems especially in the case of high sustained rates of inflation.

\section{Notes}

1. In the Philips system this reserve is the realised revaluation reserve $(10 \times 16)$; under SSAP 16 this is the current cost reserve (400-240); under AC201 there is only a current cost income statement and no current cost balance sheet; so under AC201 this amount represents retained eamings, being historical cost income (2000) minus distributable owners' income (1840).

2. Philips: realised revaluation $(10 \times 24)=240 ; \operatorname{SSAP} 16$ : current cost reserve $(\operatorname{COSA}+\mathrm{DA}+\mathrm{MWCA}-\mathrm{GA})=$ 


\section{References}

$(400-160)=240 ;$ AC201: retained earnings (historical cost income - distributed owners' income) $=2000-1760=$ 240.
Van Hoepen, M.A., Lambrechts, IJ. \& MosterL, F.J. 1989. The gearing adjustment in inflation accounting: the financing sequence assumption. $S$ Afr. J. Bus. Manage., vol. 20: 164-167. 